\title{
El cine y el vídeo en las instituciones museísticas españolas. Conflicto de catalogación y presentación
}

\section{The film and video in Spanish museum institutions. Conflict of cataloging and presentation}

Dr. Mikel Imanol Rotaeche González de Ubieta Profesor ad honorem de la Facultad de Bellas Artes (UCM) Restaurador (Museo Nacional Centro de Arte Reina Sofía)

Fecha de recepción: 8 de marzo de 2014

Fecha de revisión: 14 de julio de 2014

Para citar este artículo: Rotaeche González de Ubieta, M.I. (2014): El cine y el vídeo en las instituciones museísticas españolas. Conflicto de catalogación y presentación, Icono 14, volumen (12), pp. 441-474. doi: 10.7195/ ri14.v12i2.684 


\section{Resumen}

Las obras de arte realizadas en soportes cinematográficos y magnéticos, son parte imprescindible del arte contemporáneo. Sin embargo, su incorporación al discurso museológico y museográfico ha sido muy desigual. Mientras que el vídeo ha estado expuesto desde su aparición, al cine le ha costado casi un siglo entrar en el museo como obra de arte independiente y no como mero "documental". Este desigual tratamiento ha provocado que su comprensión técnica y estética sea deficitaria. El vocabulario necesario para la catalogación es difuso y provoca errores de registro que redundan en la preservación de este importante patrimonio. Mediante el análisis de los términos validados por el Ministerio de Cultura, el vocabulario específico usado por las principales instituciones artísticas de nuestro país y un caso de estudio se podrá demostrar que este tipo de obras de arte requiere de una terminología específica que asegure su correcto tratamiento y presentación.

Palabras clave: Cine - Vídeo - Museología - Museografía - Preservación - Exposición

\section{Abstract}

Artworks on film and video are in the core of contemporary art practice. Despite this, their integration to museum collections has been quite erratic. While video has been exhibited as soon as it has appeared, film has waited almost a century to acquire the status of "artwork" and to lose the consideration of documentary material. This difference in management has provoked a poor comprehension of their technical and artistic dimension. The specific vocabulary used to catalogue is imprecise and creates misinterpretation in the record of information, which has a bad effect on preservation. The analysis of the official vocabulary of the Ministry of Culture, the one used by the main artistic institution in the country, and a case of study it would be possible to demonstrate how relevant is to use a clear and specific terminology to allow a proper treatment and exhibition of these important contemporary heritage.

Key Words: Film - Video - Museology - Museography - Preservation - Exhibition 


\section{Introducción}

El cine y el vídeo son medios artísticos usados por los artistas para crear obras de arte contemporáneas desde su irrupción en la escena artística. En el caso del cine esta fecha se remonta el nacimiento de las vanguardias artísticas, a principios del siglo XX, de la mano de artistas como Hans Richter, Fernand Leger o Viking Eggeling ${ }^{1}$, mientras que en el caso del vídeo esto ocurre en la década de los años sesenta del mismo siglo, con artistas como Nam June Paik ${ }^{2}$, Wolf Vostel o Joan Jonas, por citar unos pocos ejemplos representativos. La incorporación del cine como obra de arte a las colecciones museísticas, no obstante, ha sido tardía y aún es minoritaria ${ }^{3}$ a pesar de haber sido uno de los principales medios de innovación de las vanguardias. Con el vídeo, sin embargo, no ha ocurrido lo mismo: su incorporación fue rápida y elevada desde su aparición. De este modo, el número de obras con soporte de este tipo en colecciones institucionales es muy superior al del cine.

La catalogación y exposición de este tipo de patrimonio artístico presenta problemas serios de asimilación cuando se incorporan al discurso museológico y museográfico, tanto que comprometen su integridad artística y material. Este déficit de compresión de su dimensión conceptual y material pone en peligro su preservación y transmisión a las futuras generaciones. Esto se debe a que, como se ha mencionado, la incorporación de estos dos medios a las colecciones institucionales $\mathrm{y}$ a sus exposiciones permanentes es irregular y desigual.

Por otro lado, la anecdótica similitud de los dos medios ha hecho que la confusión de ambos como uno solo sea habitual, tanto para el espectador como para el gestor. La existencia de obra audiovisual dentro de la sala de exposiciones ${ }^{4}$ es un hecho al que el público se ha acostumbrado desde la década de los años setenta del siglo $\mathrm{XX}$, gracias a la profusión de performances, happenings y piezas de vídeo que se producían en la época. Las galerías se llenaron de pantallas, al igual que las ferias especializadas y, al poco tiempo, los principales museos de arte contemporáneo. En la sala de exposiciones encontramos bancos corridos en lugar de las confortables butacas, pero el espacio, el cubo negro, es el mismo que en una sala de proyecciones comercial, por lo que el público asistente no duda de que está ante una proyección de cine, aunque lo que estén viendo sea, como ocurre en muchas ocasiones, una pie-

DOI: ri14.v12i2.684 | ISSN: 1697-8293 | Año 2014 Volumen 12 № 2 | ICONO14 
za de vídeo reproducida por un proyector digital. Del mismo modo, nadie se extraña al ver una obra cinematográfica reproducida en una pantalla de televisión, colocada sobre una peana. Se asume que la obra es la misma y que en realidad se ha cambiado el cubo negro de proyecciones, por un monitor negro, que al estar sobre una peana adquiere el estatus de tótem, por lo que la pieza reproducida es, sin duda, una obra de arte. No es casual, por lo tanto, que en muchas ocasiones se haya asumido que el vídeo era una prolongación del cine y que, en último término, eran lo mismo.

En este sentido hay que denunciar que el uso indiscriminado del término "audiovisual" ${ }^{\prime 5}$ ha generado una confusión que es necesario aclarar para poder abordar de forma eficaz y coherente la gestión y preservación de este importante legado. Las lagunas en el proceso de recogida y grabado de datos específicos generan, a su vez, un problema de conservación a largo plazo ya que la información es incompleta o errónea. Esto supone un serio obstáculo para la preservación del patrimonio artístico cinematográfico y magnético, ya que la catalogación de estas obras está incompleta, cuando no es incorrecta, y al estar reflejadas en catálogos publicados contribuye a amplificar y consolidar la confusión mencionada.

\section{Método}

Para poder analizar y demostrar que el patrimonio artístico cinematográfico y videográfico contemporáneo están sufriendo un problema de exposición y catalogación, y por ende de preservación, se va a abordar el estudio en tres partes diferenciadas, pero conectadas entre sí: su catalogación, el vocabulario específico en uso y la presentación o exposición institucional.

En la primera fase se va a analizar el principal tesauro técnico oficial existente, redactado y publicado por el Ministerio de Cultura en 2013. Se trata del Tesauro y Diccionario de objetos asociados a la expresión artística ${ }^{6}$, coordinado por Isabel Lafuente. Este texto posee un capítulo completo de términos de catalogación relacionados con la imagen que, al ser la referencia creada por el Ministerio de Cultura, se transforma en la fuente principal terminológica de catalogación y presentación para los museos estatales y, por extensión, en el canon que el resto de instituciones van a adoptar a la hora de analizar sus fondos artísticos.

ICONO14 | Año 2014 Volumen 12 Nº 2 | ISSN: 1697-8293 | DOI: ri14.v12i2.684 
En la segunda fase se va a presentar un análisis de cómo las principales instituciones artísticas contemporáneas catalogan este tipo de obras y cuál es el vocabulario específico que utilizan para describirlas de forma objetiva. Se van a analizar las colecciones de: el Museo Vasco de Arte Contemporáneo Artium, el Centro Andaluz de Arte Contemporáneo (CAAC), el Museo Guggenheim Bilbao, el Instituto de Arte Moderno de Valencia (IVAM), Museo de Arte Contemporáneo de Barcelona (MACBA), el Museo de Arte Contemporáneo de Castilla y León (MUSAC) y el Museo de Arte Contemporáneo Español Patio Herreriano, además de la del Museo Nacional Centro de Arte Reina Sofía ${ }^{7}$, que es el principal caso de estudio de la presente investigación y que se presentará en la tercera fase. Este caso de estudio permite ilustrar cómo el uso de un vocabulario difuso e incorrecto en el proceso de catalogación provoca problemas de presentación y de preservación que afectan al patrimonio artístico.

\section{Desarrollo}

\section{$1^{\text {a }}$ fase. Análisis del tesauro de términos específicos}

La catalogación de las obras de arte realizadas en soportes magnéticos y cinematográficos es, como se ha descrito previamente, compleja dada la falta de vocabulario específico que, a pesar de existir, no se ha incorporado debido a la resistencia de la propia institución artística. Es precisamente a causa de su fuerte componente tecnológico que los medios artísticos más contemporáneos adolecen de vocabulario técnico específico. Esta falta de conocimiento experto, tanto en los artistas como en los profesionales que después gestionan estas obras de arte, en museos y galerías, perpetúa los errores y los consolida. Como se verá en la segunda fase de esta investigación es habitual encontrar términos erróneos o inexactos, como ocurre con "audiovisual", "videoinstalación", "vídeo digital”, "proyección digital", "proyección de vídeo" y otros, recogidos en los catálogos de las principales instituciones artísticas del país.

Para poder erradicar esta mala praxis e incorporar los términos adecuados no es necesario realizar una investigación profunda, ya que en el año 2013 el Ministerio de Cultura publicó un tesauro sobre objetos y técnicas relacionados con las

DOI: ri14.v12i2.684 | ISSN: 1697-8293 | Año 2014 Volumen 12 № 2 | ICONO14 
artes plásticas y aplicadas titulado Tesauro y Diccionario de objetos asociados a la expresión artística ${ }^{8}$, que se enmarca dentro de la política de elaboración de una biblioteca de tesauros de referencia ${ }^{9}$ iniciada años antes. En este tesauro existe un capítulo completo relacionado con la creación en torno a la imagen y en él se pueden encontrar los términos básicos y necesarios para catalogar una obra de arte realizada en soporte magnético o cinematográfico. Su autora, Isabel Lafuente, ha colaborado con un gran número de instituciones nacionales para poder elaborar esta herramienta de trabajo que se inscribe dentro del programa de catalogación mediante la base de datos DOMUS y que, por tanto, va a ser de gran ayuda para un buen número de instituciones. Este tesauro, a pesar de ser muy ambicioso y completo, presenta algunas lagunas y errores que hay que detectar y subsanar para garantizar que el proceso de identificación y catalogación de las obras de arte en soporte magnético y cinematográfico sea riguroso.

Después de analizar el tesauro e identificar sus debilidades, en el campo específico del vídeo y el cine, se ha llegado a la conclusión de que los términos ausentes, pero necesarios, para poder catalogar de forma precisa una obra de arte con soporte magnético o cinematográfico son los siguientes:

\section{Bucle}

Sistema de reproducción propio de los sistemas de reproducción de CD, DVD, Laser Disc y Blue Ray que consiste en repetir el contenido del disco en un ciclo continuo e ininterrumpido, de principio a fin. También se puede usar en sistemas informáticos. Es habitual encontrar el anglicismo "loop" para hacer referencia a este tipo de sistema, pero se recomienda el uso de "bucle" por existir en castellano y ser un uso pertinente.

\section{Calibrado}

Véase "etalonaje". Se recomienda el uso del término en castellano ya que se trata de una palabra con significado preciso y ajustado al proceso al que hace referencia el galicismo en cuestión. 


\section{Copia de exposición}

Copia realizada a partir de la "copia estándar" y que se utiliza con el fin exclusivo de su proyección durante el proceso expositivo. Una vez finalizado, esta copia debe ser destruida ya que no es un soporte de preservación que pueda mantener en el tiempo las cualidades del original. En el caso de las obras de arte con soporte de vídeo, el sistema habitual es la grabación en DVD y su reproducción en bucle. En el caso del cine, lo recomendable es que sea una copia realizada en soporte de poliéster, respetando el formato original $(35 \mathrm{~mm}, 16 \mathrm{~mm}, 8 \mathrm{~mm} 0$ Super $8 \mathrm{~mm})$.

\section{Copia de consulta}

Copia realizada a partir de la "copia estándar" y que se utiliza con el fin exclusivo de investigación y consulta. Es habitual, por lo tanto, que la información esté digitalizada y disponible en un dispositivo informático o incluso en una intranet local o Internet con acceso público o restringido. Su calidad es menor que la de la "copia estándar" ya que para eliminar peso se aplican procesos de compresión de la información que favorecen la aparición de artefactos en la imagen reproducida. Este tipo de copias no puede usarse en el proceso expositivo ni en el de conservación, ya que no posee el mismo grado de calidad que la obra original.

\section{Copia de preservación}

Copia de alta calidad que se realiza directamente del original con la intención de crear una copia maestra que conserve todas las propiedades estéticas y auditivas de la obra original que se pretende preservar. Existe un consenso general en el ámbito internacional que recomienda el uso del Betacam digital, soporte magnético digital, para las copias de preservación de obras de vídeo y el uso de poliéster para las copias de preservación de obras cinematográficas. Este término también se utiliza para los soportes magnéticos.

DOI: ri14.v12i2.684 | ISSN: 1697-8293 | Año 2014 Volumen 12 №2 | ICONO14 


\section{Copia de preservación secundaria}

Copia análoga a la de "preservación" que posee las mismas cualidades y calidades pero que se usa para crear "copias de consulta" y "copias de exposición" hasta que este soporte pierda la capacidad de mantener las cualidades y calidades estéticas de la obra original. A partir de ese momento, la "copia de preservación secundaria" se elimina y se realiza otra a partir de la "principal". De este modo se reduce la manipulación de la copia original, conservando sus propiedades originales sin alteraciones derivadas de la reproducción. Este término también se usa para soportes magnéticos.

\section{Copia de proyección (cine comercial)}

Material de reproducción destinado al consumo comercial en salas de proyección para público general. En el caso de las obras de cine comercial, estas copias pueden tener montajes alternativos, con escenas añadidas o eliminadas, metraje extendido u otro tipo de contenidos extraordinarios. En el caso de la obra artística esta copia no es habitual.

\section{Etalonaje}

Proceso de ajuste, corrección y homogeneización de los valores lumínicos, cromáticos, de contraste y de enfoque de la obra cinematográfica. Se trata de un galicismo que proviene, en primera instancia, del término "étalon" que significa en su primera acepción "semental" y que de esta deriva a la segunda, que significa "referencia" 0 "patrón". La palabra "étalonnage", que es de donde procede en realidad el préstamo lingüístico, significa "calibrado" y su uso no se restringe al proceso cinematográfico o de imagen sino a todos aquellos procesos que requieren de un ajuste preciso, por lo que en castellano es pertinente el uso de la palabra "calibrado", por ser un término recogido en nuestro diccionario y que posee el mismo significado. No obstante, no se puede ignorar que en la industria del cine comercial la inserción y aceptación del término "etalonaje" es de tal envergadura que su eliminación no es posible. A pesar de esta realidad, es posible evitar el galicismo en el campo de la museología y la conservación de patrimonio artístico si se introduce y acepta el término en castellano.

ICONO14 | Año 2014 Volumen 12 N² 2 | ISSN: 1697-8293 | DOI: ri14.v12i2.684 


\section{Filmar}

Según el Diccionario de la Real Academia de la Lengua "filmar" significa, en su primera acepción, "registrar imágenes en una película cinematográfica", lo que remite evidentemente al proceso cinematográfico. En su segunda acepción significa "rodar una película", por lo que el término queda vinculado por completo al hecho cinematográfico. Se trata, por lo tanto, del término específico que debe usarse para hacer referencia, de forma exacta, al proceso de registro de la imagen en un soporte cinematográfico, sea este del tipo que sea. No se recomienda el uso de "grabar", a pesar de que en su segunda acepción signifique "captar y almacenar imágenes o sonidos por medio de un disco, una cinta magnética u otro procedimiento, de manera que se puedan reproducir", ya que no se trata de un proceso específico y exclusivo de la cinematografía.

\section{Filmación}

Proceso de filmar, véase "filmar".

\section{Fotograma}

El tesauro Lafuente no incorpora el término "fotograma", lo cual resulta llamativo al abordar la sección específica de "diccionario de objetos asociados a la imagen". ${ }^{10}$ Según la Real Academia Española "fotograma" es un sustantivo masculino que hace referencia a "cada una de las imágenes que se suceden en una película cinematográfica". ${ }^{11}$ Por lo tanto, el uso de "fotograma" no solo es pertinente sino imprescindible, por poseer una fuerte presencia en el lenguaje técnico, profesional y coloquial. Se desaconseja, por otro lado, el uso de "filmina" ya que puede provocar la confusión con una diapositiva o transparencia, como se verá más adelante. ${ }^{12}$

\section{Grabar}

Según el diccionario de la Real Academia Española "grabar" es un verbo transitivo que significa, en su segunda acepción, “captar y almacenar imágenes o sonidos por medio de un disco, una cinta magnética u otro procedimiento, de manera que 
se puedan reproducir." ${ }^{13}$ En el caso del vídeo, el proceso de grabación o “grabación", en sí misma, es el momento en el que se recogen las imágenes y escenas seleccionadas con la cámara de vídeo y estas se fijan en la cinta magnética que se encuentra en su interior. En este proceso no existe edición, más allá de la propia parada y reanudación de la grabación.

\section{Grabación de vídeo}

Según Lafuente, es sinónimo de Videograbación. ${ }^{14}$ Sin embargo, se recomienda usar el término "grabación" o incluso "grabación de vídeo" por ser una combinación pertinente y con significado exacto en castellano. En el caso del vídeo, el uso de "grabación" es correcto, ya que hace referencia al proceso en sí mismo, sin necesidad de añadir "de vídeo", que queda sobrentendido y podría llegar a ser redundante, como ocurriría al formar la frase "filmar cine" o "filmación de cine". Por lo tanto, el uso de "grabación", cuando se está catalogando una obra de arte en vídeo, es pertinente y correcto puesto que aporta la información necesaria sobre el proceso.

\section{Master}

Anglicismo que, en el caso de la cinematografía, hace referencia a la "copia estándar" o "copión de montaje" donde se encuentran las cualidades originales de la obra. Su existencia permite hacer "copias de preservación" de las que extraer, después, las "copias de exhibición" y "copias de consulta" necesarias sin alterar el estado de conservación de la obra original. Puede tratarse de una copia original o de un original en sí mismo, en función de lo que el autor haya determinado. Este término se utiliza tanto para los soportes magnéticos como para los cinematográficos, con el mismo significado.

\section{Master de preservación}

Véase "copia de preservación". Se recomienda el uso de "copia de preservación" al ser una combinación pertinente y de significado exacto en castellano. 


\section{Submaster}

Anglicismo que, en el caso de la cinematografía, hace referencia a la segunda "copia de preservación" realizada a partir de la "copia estándar" o "master" y que se usa, exclusivamente, para obtener el número que se considere conveniente de copias de "consulta" y de "exhibición" sin alterar las condiciones de conservación de la obra original. Mientras esta copia conserve las cualidades originales de la obra, se podrán hacer tantas copias como sean necesarias. Una vez perdidas estas cualidades, será necesario hacer otra copia a partir de la copia de preservación principal para poder seguir creando las de "consulta" y de "exhibición". Este término se utiliza tanto para los soportes magnéticos y los cinematográficos, con el mismo significado.

\section{Monitor (de imagen)}

Según Lafuente, un "monitor" es un elemento específico de la cámara de vídeo, similar a un televisor pero de muy reducidas dimensiones y cuya función es la de proporcionar al operador de cámara la imagen que está siendo recogida por esta. ${ }^{15}$ Según el diccionario de la Real Academia Española, el término "monitor" es un anglicismo que significa, en su segunda acepción, "aparato receptor que toma las imágenes directamente de las instalaciones filmadoras y sirve para controlar la transmisión", por lo que queda vinculado al acto cinematográfico y no al videográfico. Su uso, no obstante, no es específico del cine y se aplica a los televisores que se utilizan para reproducir la imagen del vídeo, tanto en la grabación como en la reproducción. La diferencia que podría aducirse para recomendar el uso de "monitor" en lugar de "televisor", en el caso del vídeo, es que este último significa "aparato receptor de televisión"; la reproducción de vídeo no es, en sí misma, una retransmisión de televisión comercial, por lo que esta diferencia podría bastar para argumentar que el monitor es específico de la reproducción de imágenes grabadas, sean estas cinematográficas o videográficas.

Antes de finalizar con el análisis del vocabulario específico necesario para catalogar y conservar adecuadamente las obras de arte en soporte cinematográfico y magnético, hay que recordar que el lenguaje construye el conocimiento, ergo

DOI: ri14.v12i2.684 | ISSN: 1697-8293 | Año 2014 Volumen 12 № 2 | ICONO14 
su uso debe ser pulcro y ajustado a la realidad que se pretende describir. De otro modo se estará incurriendo en una confusión que, no siendo premeditada, es igual de grave al proceder de la inconsciencia. Sin un vocabulario específico contrastado y consensuado no será posible abordar la conservación del patrimonio artístico cinematográfico y videográfico con garantías y excelencia.

Por esta razón, se recomienda no utilizar los siguientes términos recogidos en el tesauro Lafuente, debido a que son inexactos o difusos:

\section{Celuloide}

Término genérico que hace referencia a todos los soportes cinematográficos (70mm, 35mm, 16mm, 9,5mm, $8 \mathrm{~mm}$ y Super $8 \mathrm{~mm}$ ) fabricados en nitrato de celulosa y acetato de celulosa hasta la introducción del poliéster en 1960. Al tratarse de un término genérico, no permite aportar información específica sobre el material. Su uso debe restringirse a casos muy concretos y aislados.

\section{Filme}

Según el diccionario de la Real Academia Española "filme" significa "película cinematográfica" de forma genérica, sin especificar formato o duración. Se trata de un término específico, como no cabe duda, de la industria cinematográfica. El sinónimo "película" se puede usar cuando se hace referencia a las de distribución comercial y no a las obras de arte producidas en soporte cinematográfico.

\section{Filmina}

Según Lafuente, una "filmina" es una tira de película, generalmente de 16 a 35mm, que contiene una sucesión de imágenes estáticas (fotografias, ilustraciones gráficas y/o textos) destinadas a ser proyectadas una por una, con sonido o sin él. Pueden presentarse sueltas o montadas en carretes. ${ }^{16} \mathrm{~A}$ pesar de que Lafuente recomienda su uso, al incorporarlo en su tesauro, resulta pertinente señalar que el uso de "fotograma" es mucho más preciso y apropiado en el caso de la obra cinematográfica y videográfica, ya que posee un significado preciso y elimina las posibles confusiones. Por otro lado,

ICONO14 | Año 2014 Volumen 12 NN$^{\circ} 2$ | ISSN: 1697-8293 | DOI: ri14.v12i2.684 
el diccionario de la Real Academia Española define "filmina", en sus dos acepciones reconocidas, como diapositiva, ${ }_{17}^{17}$ que a su vez significa "fotografía positiva sacada en cristal u otra materia transparente". Como se puede comprobar, esta definición no hace referencia al soporte cinematográfico, aunque se pueda considerar como un material transparente, por lo que su uso no es apropiado ya que la confusión no se basa en una sinonimia sino en un intercambio de términos. Se desaconseja, por lo tanto, su uso para hacer referencia al fotograma cinematográfico o para hacer referencia a las dos mitades entrelazadas que componen las imágenes de vídeo.

\section{Película cinematográfica}

Término genérico que hace referencia a un soporte plástico, fino y transparente, que puede poseer anchos variables de entre $8,16,35070 \mathrm{~mm}$. El soporte que se utiliza en la actualidad es poliéster pero es posible encontrar soportes históricos fabricados en nitrato de celulosa, acetato, diacetato y triacetato de celulosa.

\section{Videocinta}

Según el tesauro, es una cinta magnética en la que se pueden grabar textos, imágenes o sonidos reproducibles en pantalla de televisión. ${ }^{18}$ Este investigador recomienda el uso de "cinta", ya que es un soporte magnético y la adición del prefijo "video-" no aporta ninguna diferencia cualitativa. Por otro lado, el uso del término "videocinta" es, en todo caso, residual.

\section{Videodisco}

0curre lo mismo que con el término compuesto del apartado anterior, por lo que se recomienda usar el sustantivo "disco".

\section{Videograbación}

No se recomienda su uso, a pesar de estar recogido en el tesauro Lafuente, ya que en castellano es pertinente el uso del binomio "grabación de vídeo", o simplemente, "grabación". El diccionario de la Real Academia Española recoge el término

DOI: ri14.v12i2.684| ISSN: 1697-8293 | Año 2014 Volumen 12 № 2 | ICONO14 
y lo define como "grabación hecha en vídeo"19. Como se ha visto previamente, "grabar", en su segunda acepción, significa "captar y almacenar imágenes o sonidos por medio de un disco, una cinta magnética u otro procedimiento, de manera que se puedan reproducir", por lo que hacer referencia al vídeo podría considerarse una redundancia en el significado, ya que la propia definición incorpora "cinta magnética", es decir, un soporte genérico en el que se incluye el vídeo, así como las cintas de audio y otros soportes informáticos digitales. Mientras que el proceso cinematográfico posee una palabra específica, "filmar", el vídeo carece de ella y este término, en opinión de este investigador, es un intento de acuñar un término ex novo que, a pesar de aparentar precisión, no es pertinente.

\section{$2^{\text {a }}$ Fase. Análisis de la catalogación usada por las principales ins- tituciones de arte contemporáneo nacionales}

Tras analizar el tesauro Lafuente y diagnosticar sus fortalezas y debilidades ,no cabe duda de que el proceso de catalogación de las obras de arte cinematográficas y videográficas presenta un problema de concreción que dificulta su correcta identificación e integración en una colección museística o institucional. Si los términos usados para registrar el soporte, el formato o incluso el medio son difusos o incorrectos, es lógico suponer que las tareas de investigación, presentación, conservación y restauración tendrán que superar serias dificultades al no poder describir de forma objetiva la realidad a la que se enfrentan. Para poder ilustrar que se trata de un asunto de suma importancia, es necesario comprobar cómo se ha realizado la catalogación de estas obras de arte en las principales instituciones de nuestro país. De este modo, se podrá ofrecer un diagnóstico ajustado de la práctica profesional que ayudará, como se verá en la tercera fase, a comprobar si la presentación de estas obras de arte es pertinente o no.

\section{A) Museo Vasco de Arte Contemporáneo ARTIUM}

La colección del Museo Vasco de Arte Contemporáneo Artium pertenece a la Diputación Foral de Álava, que comenzó a comprar obras de arte de forma activa en la década de los años setenta del siglo XX. El museo se gestiona mediante la participación de la Fundación ARTIUM. Esta fundación es una entidad sin ánimo de

ICONO14 | Año 2014 Volumen 12 Nº 2 | ISSN: 1697-8293 | DOI: ri14.v12i2.684 
lucro, constituida en febrero de 2001 por la Diputación Foral de Álava, con el fin de dirigir y gestionar el museo. Su Patronato está constituido por las instituciones públicas que participaron en su construcción ${ }^{20}$ y por las entidades empresariales privadas que forman parte de la fundación como patronos. ${ }^{21}$

La colección de Artium está compuesta por 3000 obras de arte que van "desde la pintura y la escultura hasta la fotografía, el vídeo y la instalación". ${ }^{22}$ La colección de soportes magnéticos esta compuesta, a fecha de 30 de diciembre de 2012, por 91 obras y en su catálogo solo se detecta una obra en soporte cinematográfico ${ }^{23}$, que además está transferida a vídeo. En el catálogo de 2004, no obstante, sólo aparecen referenciadas 8 obras de vídeo, sin especificar los soportes o técnicas en su ficha catalográfica. En este sentido el propio catálogo señala que:

"Técnica y soporte: enumera los materiales utilizados e indica el soporte sobre el que se ha ejecutado la obra (...) En escultura e instalaciones "objetos varios" $y$ "materiales diversos" son los términos que designan la diversidad de materiales y objetos". ${ }^{24}$

De la lectura de estas pautas, que además están recogidas en el apartado titulado "notas sobre la catalogación", queda demostrado que, en el caso concreto de obras complejas que se salen de los parámetros tradicionales de catalogación, se ha optado por utilizar términos genéricos que en lugar de despejar dudas, mediante el uso de información concluyente, aumentan, o al menos perpetúan, el desconocimiento en torno a este tipo de materiales y técnicas.

\section{B) Centro Andaluz de Arte Contemporáneo (CAAC)}

El Centro Andaluz de Arte Contemporáneo (CAAC) se creó en 1990, mediante la Ley de 2 de febrero de 1990 del Presupuesto de la Comunidad Autónoma de Andalucía, como Organismo Autónomo dependiente de la Consejería de Cultura. Se le otorgó personalidad jurídica y patrimonio propio, así como autonomía administrativa y financiera para operar de forma pública y privada. En 1997 se aprobaron sus nuevos estatutos, mediante el Decreto 195/1997 de 29 de julio, y se reorganizó el centro para aumentar su presencia y acción pública, relacionada con el arte contemporáneo. Ese mismo año

DOI: ri14.v12i2.684 | ISSN: 1697-8293 | Año 2014 Volumen 12 № 2 | ICONO14 
la Cartuja de Santa María de las Cuevas de Sevilla, que había sido restaurada para la Exposición Universal de Sevilla de 1992, se transformó en su sede permanente.

El CAAC tiene establecidas las siguientes funciones:

- La constitución de una colección permanente de Arte Contemporáneo.

- El desarrollo de exposiciones temporales de Arte Contemporáneo.

- La conservación de los fondos artísticos contenidos en el Centro, así como la restauración de los fondos de carácter permanente cuando sea necesario.

- La investigación en materia de Arte Contemporáneo.

- El fomento y difusión del Arte Contemporáneo con especial atención a la producción de los jóvenes artistas de la Comunidad Andaluza. ${ }^{25}$

El CAAC es, de los museos analizados en el presente apartado, el único que utiliza la base de datos DOMUS para registrar y catalogar las obras pertenecientes a su colección. Existen 38 obras catalogadas bajo el epígrafe "audiovisual" pero sin especificar el tipo de soporte, el sistema de reproducción o la duración del contenido grabado en el soporte.

\section{C) Museo Guggenheim Bilbao}

El Museo Guggenheim Bilbao pertenece a la red internacional de Museos Guggenheim, formada por el Solomon R. Guggenheim Museum de Nueva York, el Peggy Guggenheim Collection de Venecia y el Guggenheim Abu Dhabi, actualmente en proyecto de ejecución. Todos ellos son gestionados por la Solomon R. Guggenheim Foundation, fundada en 1937, que tiene la misión, establecida en sus estatutos de fundación, de promover la comprensión y apreciación del Arte Contemporáneo, así como de la arquitectura y otras manifestaciones de la cultura visual moderna y contemporánea. Sus principales objetivos son coleccionar, conservar e investigar el arte desde las vanguardias históricas de principios del siglo XX a la creación contemporánea.

ICONO14 | Año 2014 Volumen 12 Nº 2 | ISSN: 1697-8293 | DOI: ri14.v12i2.684 
Según la Memoria de Actividades del año 2011, la colección propia del Museo Guggenheim Bilbao está compuesta por 124 obras $^{26}$, de las cuales sólo 3 tienen soportes magnéticos, un vídeo ${ }^{27}$ y dos proyecciones, una de DVD ${ }^{28}$ y la otra en $\mathrm{HD}^{29}$ ("High Definition"), pero sin especificar el soporte. Según su catálogo impreso y su versión electrónica, en la colección de Bilbao no hay ninguna obra con soporte cinematográfico.

\section{D) Instituto Valenciano de Arte Moderno (IVAM)}

El Instituto Valenciano de Arte Moderno (IVAM) fue creado por la Ley 9/1986 de 30 de diciembre de la Generalitat Valenciana, de acuerdo con lo establecido en la Ley 5/1982, sobre el estatuto de autonomía de la Comunidad Valenciana. En su artículo 31.4, se establece que son competencias de la Generalitat la tutela, fomento y difusión del arte moderno. El IVAM se configura, por tanto, como una entidad de derecho público ${ }^{30}$ dependiente de la Generalitat Valenciana ${ }^{31}$ en el ejercicio legítimo de sus competencias de cultura. Esta adscrito a la Consejería de Cultura, Educación y Deporte y tiene plena capacidad de obrar para el cumplimiento de sus fines.

La colección del IVAM está formada por 10600 obras. Su núcleo principal es el conjunto de obras de Julio González, formado por 394. La colección se divide en cinco grandes recorridos o ejes, denominados: Fotografía y fotomontaje, Instalaciones y nuevos medios, Abstracción, Pop Art, Escultura y Obra sobre papel. Según el catálogo Instalaciones y Nuevos Medios en la colección del IVAM. Espacio, tiempo, espectador, la colección de soportes magnéticos está formada por 11 obras y la colección de soportes cinematográficos por 3 obras ${ }^{32}$, las tres son soportes de $16 \mathrm{~mm}$ transferidos a DVD. Según este catálogo no existen obras en $35 \mathrm{~mm}, 8$ o Super $8 \mathrm{~mm}$. En cuanto a los soportes magnéticos, no se especifica su naturaleza ni formato. Es importante señalar que los soportes magnéticos y cinematográficos aparecen en un mismo catálogo bajo la denominación "instalaciones y nuevos medios", que en este caso podría considerarse análoga a "audiovisuales", ya que pretender englobar bajo un mismo epígrafe diferentes prácticas artísticas de difícil catalogación pero que, con la información que existe actualmente, pueden ser segregadas dado que pertenecen a medios artísticos diferentes.

DOI: ri14.v12i2.684 | ISSN: 1697-8293 | Año 2014 Volumen 12 № 2 | ICONO14 
En el catálogo que la institución tiene disponible en Internet ocurre lo mismo y este tipo de obras solo puede consultarse desde la sección "Instalaciones y Nuevos medios", en la que se explica lo siguiente:

"En la colección hay instalaciones de ocupación mural como son la de Baldessari, McCollum o Quejido; instalaciones que, aun con una ocupación tridimensional del espacio, mantienen una lectura frontal llegándose a disfrazar de espacios cotidianos como son las de Carmen Calvo, Evaristo Navarro o Ricardo Cotanda; hay piezas que se sitúan en los limites de la escultura ya que conservan un discurso interno y crean un espacio no abordable por el espectador -los casos de Susy Gómez, Tony Cragg, Cabrita Reis, Miquel Navarro, Nacho Criado, Emilio Martínez o Jordi Colomer-; obras en las que se exige una participación más allá de lo visual por parte del espectador como las de Joan Fontcuberta o Lothar Baumgarten; obras que se completan con el movimiento del usuario como la de José Antonio Orts; vídeo instalaciones de Antoni Muntadas y Gary Hill; piezas que se acercan a lo arquitectónico como las de Boltanski, Bruce Nauman, Juan Muñoz o Gilberto Zorio o que directamente se travisten en arquitectura como la Fun House de Hamilton o la pieza de Victoria Civera". ${ }^{33}$

Mediante esta descripción se vuelve a demostrar que el vídeo o el cine, como medios de creación artística reconocidos y diferenciados, acaban mezclados con otros, como la instalación o el net art, debido a las dificultades derivadas de catalogar los medios de creación contemporáneos mediante herramientas de catalogación tradicionales.

En el catálogo de la colección de $2001^{34}$ no aparece ninguna obra en soportes magnéticos o cinematográficos, lo cual resulta llamativo, ya que cinco años después es cuando se edita el catálogo titulado Instalaciones y nuevos medios en la colección del IVAM, en el que aparecen las catorce obras indicadas previamente.

\section{E) Museo de Arte Contemporáneo de Barcelona (MACBA)}

El Museo de Arte Contemporáneo de Barcelona (MACBA) es un consorcio formado por el Ayuntamiento de Barcelona y la Generalitat de Catalunya, que cuenta, ade-

ICONO14 | Año 2014 Volumen 12 N² | ISSN: 1697-8293 | DOI: ri14.v12i2.684 
más, con la contribución de otras entidades, como la Diputación de Barcelona, y de particulares que han realizado donaciones y acuerdos de depósito. En este sentido, se debe destacar el papel de la Fundació MACBA, constituida en 1987 y encargada del programa de adquisiciones, que permite aumentar su patrimonio artístico. En 2007, el Ministerio de Cultura se incorpora al Consorcio y, el 14 de abril de 2008, el Consejo General del Consorcio aprueba unos nuevos estatutos que definen su estructura como "ente público". En el caso del MACBA hay que señalar que existen tres administraciones distintas que velan por su correcto funcionamiento: la local (Ayuntamiento de Barcelona), la provincial (Diputación de Barcelona y Generalitat de Catalunya) y la estatal (Ministerio de Cultura).

La colección del MACBA está compuesta por $4674^{35}$ obras, aproximadamente, y se extiende desde principios del siglo XX hasta la actualidad. Las obras de soportes cinematográficos y magnéticos se encuentran catalogadas bajo los epígrafes "grabaciones audiovisuales" y "media instalación", correspondiendo a cada grupo 353 y 76 obras $^{36}$, respectivamente. En este sentido hay que destacar que el MACBA es el museo con la colección de soportes cinematográficos y magnéticos más numerosa, después de la del MNCARS, que será analizada en el apartado correspondiente al caso de estudio de la presente investigación.

En el catálogo del año 2003 las obras en soportes cinematográficos que se contabilizan son sólo 6 , todas ellas de $16 \mathrm{~mm}$. En cuanto a los soportes magnéticos sólo aparecen 10 obras, de las cuales sólo cinco aportan información sobre el soporte usado: Betacam, U-matic, VHS y betacam SP. ${ }^{37}$

\section{F) Museo de Arte Contemporáneo de Castilla y León (MUSAC)}

La Colección MUSAC está formada por 1.650 obras, y cuenta con representación de 400 artistas distintos. El punto de partida de esta colección es el año $1989^{38}$ y se prolonga hasta la actualidad, incorporando todos los años en el programa de adquisiciones, artistas jóvenes y actuales. En este sentido hay que señalar que el MUSAC pretende recoger las aportaciones artísticas de finales del siglo XX y de principios del siglo XXI.

DOI: ri14.v12i2.684| ISSN: 1697-8293 | Año 2014 Volumen 12 N² | ICONO14 
Según el catálogo disponible en Internet, de las 1650 obras que forman la colección permanente, 71 están catalogadas como "video"39 , 4 como "vídeo", 2 como "film" y ninguna como "película" 40 . Resulta llamativo comprobar que debido al error ortotipográfico de incluir o no un acento en la "i" de la palabra "vídeo" la colección de soportes magnéticos se ve alterada de forma tan sustancial. En cualquier caso, si se suman las dos cifras se obtiene una colección de 75 obras en soporte magnético, entre las que se encuentran, además de vídeo, también videoinstalaciones, vídeoinstalaciones y proyecciones, y 2 en soporte cinematográfico, ambas en $16 \mathrm{~mm}$.

Sin embargo, según los catálogos editados en 2005, 2007 y 2010 el número de obras en soportes magnéticos asciende a 151 y la colección de soportes cinematográficos, a 14 obras. En el caso del soporte cinematográfico existen 11 obras en $16 \mathrm{~mm}$ y 5 en $35 \mathrm{~mm}$.

\section{G) Museo de Arte Contemporáneo Español Patio Herreriano}

El proyecto del Museo de Arte Contemporáneo Español Patio Herreriano es el fruto de la colaboración entre el Ayuntamiento de Valladolid, titular del edificio y principal fuente de financiación, y la Colección Arte Contemporáneo, propietaria de la colección permanente del museo, cedida en comodato desde el 14 de enero de 2000, día en el que se firmó un acuerdo mediante el cual la Colección Arte Contemporáneo, integrada por 23 empresas españolas..$^{41}$ Este consorcio de empresas cedió, sin contraprestación alguna, durante cinco años, los fondos artísticos actuales y las futuras adquisiciones de su colección para el disfrute público. El comodato es renovado cada cinco años, desde 2005, año en el que se formalizó la primera prórroga.

La colección está formada por 1105 obras, de las cuales sólo 13 están catalogadas como obras de vídeo, por lo que su colección de soportes magnéticos es la segunda más reducida, precedida solo por la del Museo Guggenheim Bilbao, que tiene dos obras catalogadas. Sin embargo, según el catálogo editado en 2002 sobre la colección del museo, esta se halla formada por 851 obras, de las cuales 445 son pinturas y esculturas ( $\mathrm{sic}$ ) y las restantes 466 dibujos $^{42}$. En este catálogo no existe ninguna referencia a obras de arte realizadas en soportes magnéticos o cinematográficos.

ICONO14 | Año 2014 Volumen 12 Nº 2 | ISSN: 1697-8293 | DOI: ri14.v12i2.684 


\section{H) Museo Nacional Centro de Arte Reina Sofía}

Aunque la colección de soportes magnéticos y cinematográficos del Museo Nacional Centro de Arte Reina Sofía se va a analizar con más detenimiento en esta misma investigación, en la fase de caso de estudio, merece la pena apuntar el número de obras que están catalogadas bajo los epígrafes de vídeo y cine. La colección de soportes magnéticos es de 374 obras, mientras que la de soportes cinematográficos asciende a 81 obras. Como se verá más adelante, la catalogación de las obras es más exacta que en los casos anteriores, ya que se utilizan los epígrafes de "cine", "vídeo", "instalación" e incluso de "net art", "arte informático" y "arte sonoro". Sin embargo, y como se verá más adelante, es necesario analizar en profundidad el sistema de catalogación para poder extraer datos fiables, ya que existen epígrafes y categorías que son confusas al poder ser asignadas a la misma obra de forma simultánea, de tal modo que una sola obra puede poseer varias categorías al mismo tiempo.

Gracias a este análisis se pueden extraer varias conclusiones sobre cómo se cataloga el cine y el vídeo, como un medio artístico, en el espacio artístico institucional de nuestro país:

1. La presencia de soportes cinematográficos y magnéticos en las principales colecciones de arte contemporáneo del país es escasa, cuando no anecdótica, como en el caso del Guggenheim Bilbao.

2. La catalogación de estas obras y sus respectivos soportes es deficiente e imprecisa, ya que no aporta datos sobre tipo de soporte, sistema de entrelazado (PAL, NTSC o SECAM), duración, color y sonido.

3. Se confunden los términos de "vídeo", "videoinstalación", "proyección", "proyección digital", "grabación audiovisual", "instalación" y "media instalación".

4. Se identifica como vídeo el soporte de DVD, que no es un soporte magnético sino uno óptico.

5. La mayoría de las obras en soporte cinematográfico identificadas están transferidas a soportes ópticos, DVD, o magnéticos, como el vídeo, pero sin especificar cuál es ese soporte o el original del que procede. 
La institución con la colección de soportes cinematográficos y magnéticos más grande es el MNCARS, con 374 obras en soportes magnéticos y 81 en cinematográficos, catalogadas como vídeo y cine, respectivamente. Inmediatamente después se encuentra el MACBA, con una colección de 353 obras catalogadas como "grabaciones audiovisuales", seguida por la colección del MUSAC, con 151 obras en soporte magnético y 14 en cinematográfico. En cuarto lugar está la colección de Artium, con 91 obras catalogadas como "vídeo", de las cuales tan sólo 3 son soportes cinematográficos. Por otro lado, la colección con menor número de obras en soporte magnético o cinematográfico es la del Guggenheim Bilbao, con 3 obras de vídeo y ninguna de cine. La colección del Museo Patio Herreriano es la segunda colección con menor número de obras en soportes magnéticos o cinematográficos, con 13 obras en total. Por último, la tercera colección con menos obras catalogadas es la del IVAM, que, según su catálogo, tan solo posee 14 obras (11 en soportes magnéticos y 3 en cinematográficos).

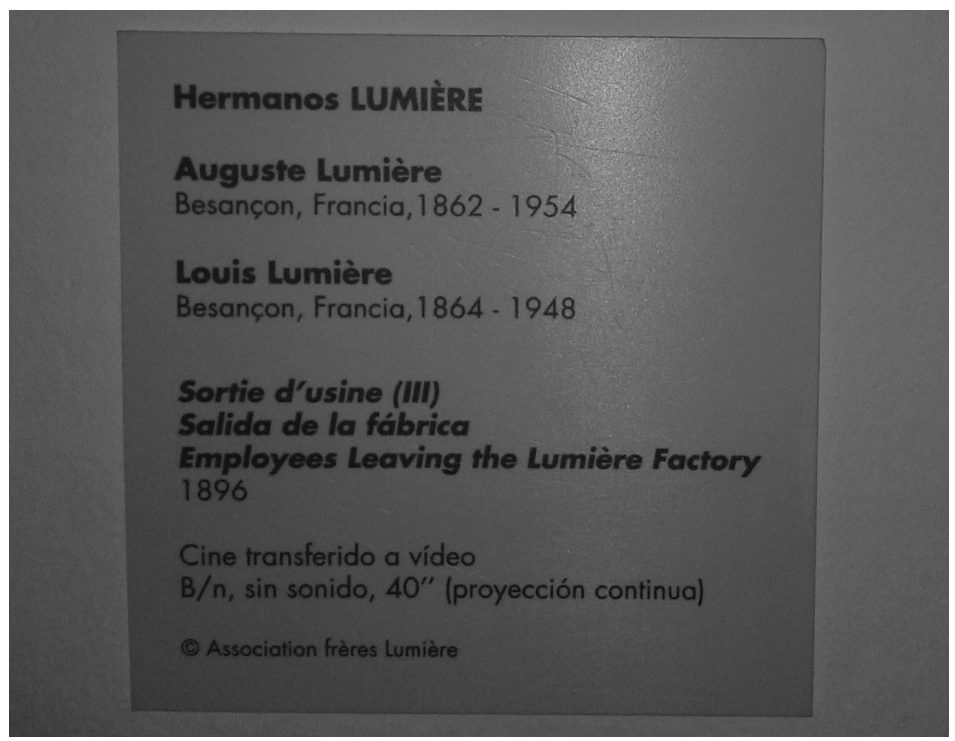

Figura 1: Detalle de una cartela dispuesta en la colección permanente del MNCARS.

\section{$3^{\text {a }}$ fase. Caso de estudio sobre la exposición del patrimonio artís- tico cinematográfico y videográfico: el MNCARS}

Tal y como se ha expuesto, el cine y el vídeo son medios diferenciados, con cualidades y características propias que los distinguen, a pesar de la falsa idea de similitud 
que pueden sugerir. La reproducción también es distinta: el cine reproduce de forma individual y continuada cada fotograma, con sus cualidades estéticas, para crear la ilusión de movimiento, mientras que el vídeo entrelaza la mitad de una imagen con la mitad de la siguiente de forma continua para obtener el mismo resultado. La imagen que se fija en la pantalla es la formada por dos mitades distintas, es decir, el fotograma original nunca se muestra completo. Por otra parte, el proceso químico del cine aporta a la imagen cualidades de nitidez y grano que en el vídeo no existen, su calidad estética es menor. En este punto hay que reivindicar las cualidades estéticas específicas de cada medio. Esto indica claramente que cada medio puede crear un lenguaje estético y formal propio, como de hecho ha ocurrido. El cine posee unos códigos propios que en el vídeo no son aplicables, o si lo son, no obtienen los mismos resultados.

Para ilustrar las consecuencias derivadas de la confusión entre ambos medios, basta con analizar la colección permanente del principal museo de arte contemporáneo nacional: el Museo Nacional Centro de Arte Reina Sofía. La elección no responde sólo a que este museo sea la principal institución nacional de arte contemporáneo, sino también a que esta situación lo transforma en la referencia ineludible para otras muchas instituciones de menor tamaño. Su posición, elegida o no, conlleva un deber pedagógico, ético e incluso epistemológico. De este sencillo ejercicio de análisis se podrán extraer unas valiosas conclusiones, que pondrán de manifiesto las áreas en las que es necesario profundizar para garantizar la correcta presentación y preservación de nuestro patrimonio contemporáneo.

Según el catálogo alojado en la página electrónica de la institución, ${ }^{43}$ existen 14 obras en soportes cinematográficos y 2 obras en soportes magnéticos expuestas en la colección permanente. El reducido número resulta sorprendente, sobre todo para un museo de esta importancia. Aun así, cuando se exploran las salas del museo, en una visita ordinaria, se puede comprobar cómo el número obtenido de la página electrónica no se corresponde con lo que se aprecia en las galerías: 65 piezas, entre cine y vídeo. De todas estas obras, tal y como proclama el catálogo electrónico, sólo 16 son propiedad del MNCARS; el resto son obras en depósito, películas comerciales o documentales, que no son obras de arte pero que están presentes en el discurso expositivo para contextualizar una tesis. Sin embargo, el público asistente se puede sentir confundido al observar la profusión de proyecciones sobre fondo blanco, fondo negro, monitores so-

DOI: ri14.v12i2.684| ISSN: 1697-8293 | Año 2014 Volumen 12 N² | ICONO14 
bre peana, sobre mesa, encastrados e incluso en ordenador que se va a ir encontrando a lo largo de la visita.

Existen 22 proyecciones sobre fondo blanco, 11 sobre fondo negro, 10 monitores sobre peana con auriculares, 4 sin auriculares, 9 sobre mesa inclinada con auriculares, 3 pantallas planas expuestas sobre la pared, una encastrada en la pared y, para finalizar, una pantalla de tubo catódico, un monitor, encastrado en la pared y sin auriculares. A esto hay que añadir que existen 3 obras que comparten la misma pantalla de proyección, tres vídeos que comparten el mismo televisor y dos vídeos que comparten la misma pantalla plana sobre la pared. En resumen, existen 61 elementos tecnológicos audiovisuales ${ }^{44}$ y 65 piezas audiovisuales ${ }^{45}$, de diferente naturaleza, conviviendo en el mismo espacio expositivo, con distintos sistemas de visualización, lo cual crea una evidente confusión, ya que el uso del lenguaje museográfico y museológico ${ }^{46}$ no es coherente.

Como se ha apuntado previamente, tan solo 16 de los 65 elementos audiovisuales son obras de la colección del MNCARS, lo que supone únicamente el $24 \%$ de todo lo mostrado. El resto de piezas audiovisuales, 49 en total, no son todas obras de arte aunque presenten cartela y ocupen un lugar en el espacio expositivo de la colección permanente. De estas 49 piezas, 31 son documentales o películas comerciales. En concreto, 8 son documentales, ${ }^{47} 22$ son películas comerciale ${ }^{48}$ y 1 es una filmación documental en el taller de un artista. ${ }^{49}$ Esto arroja otro dato interesante: el resto de piezas audiovisuales, 18 en total ${ }^{50}$, son obras depositadas que no son propiedad de la colección pero que se exponen en ella, lo cual provoca también confusión en el espectador que accede a las salas de la colección permanente. Dos de las proyecciones son material de nueva producción fabricado con la intención de crear una escenografía particular que contextualice una obra escultórica expuesta: se trata del caso de las proyecciones que rodean a la obra de Luis Alexanco Soledad Interrumpida, y que están construidas a partir de retales de imágenes creadas por el artista en colaboración con José Tejedor.

Podría dar la sensación de que estos datos son meramente anecdóticos; sin embargo, esconden una realidad museológica de gran importancia: el cine y el vídeo son dos medios artísticos infravalorados e infracatalogados. ¿Cómo se puede demostrar esta afirmación? De las 16 obras de la colección expuestas en las salas del MNCARS, 14 son

ICONO14 | Año 2014 Volumen 12 Nº 2 | ISSN: 1697-8293 | DOI: ri14.v12i2.684 
en soporte cinematográfico y 2 en soporte magnético. Todas ellas, las 16 obras, usan el DVD para su exposición, es decir, han sido transferidas a un soporte óptico. En el caso del vídeo no hay una diferencia sustancial, pero el cine debe ser transferido a un sistema de entrelazado de imagen para poder ser grabado en DVD, lo que significa que la imagen cinematográfica, el fotograma unitario, se pierde para siempre, ya que en la pantalla siempre aparecerán la mitad de un fotograma y la mitad del posterior, entrelazados, como se ha explicado previamente. Esto significa que el 100\% de las obras cinematográficas esta siendo expuesta de forma incorrecta, al haber sido cambiado su medio de reproducción natural. Una obra artística en soporte cinematográfico debería ser expuesta en soporte cinematográfico. Nadie entendería que en lugar del Gernika se expusiera una lámina, por muy buena que esta fuese. Pero hay que proseguir en esta línea y analizar si todas las obras cinematográficas, a pesar de estar transferidas a vídeo y después a DVD, son expuestas mediante proyección, respetando, al menos, los valores tradicionales de la experiencia cinematográfica (sala oscura, asientos y sonido frontal). De las 14 obras de arte en soporte cinematográfico de la colección expuestas en las salas, 4 de ellas son proyecciones sobre fondo negro, 4 sobre fondo blanco, 2 en monitor de tubo catódico sobre peana y sin auriculares, 2 sobre monitor en mesa inclinada sin auriculares $\mathrm{y}$, por último, 2 en pantalla plana sobre pared. Por lo tanto, tan solo 4 de las obras cinematográficas del MNCARS son expuestas mediante el sistema clásico de proyección sobre fondo negro, lo que es aún más grave: 6 de ellas son expuestas en pantallas de televisión, lo que distorsiona por completo la experiencia cinematográfica y confunde al público al transmitirle el mensaje de que lo que ve es análogo a un vídeo, que solo debería verse en pantalla de televisión.

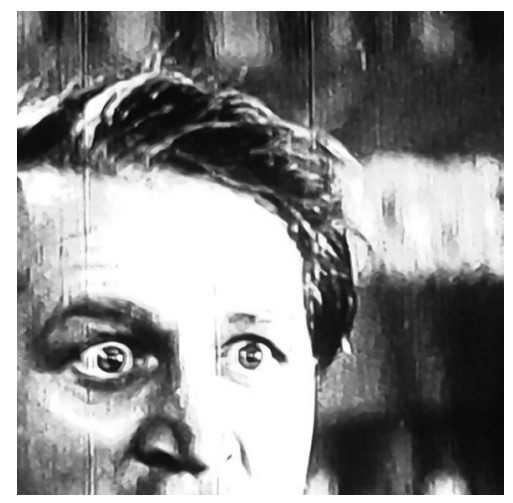

Figura 2: Detalle de una obra cinematográfica, migrada a DVD y mostrada en monitor. 


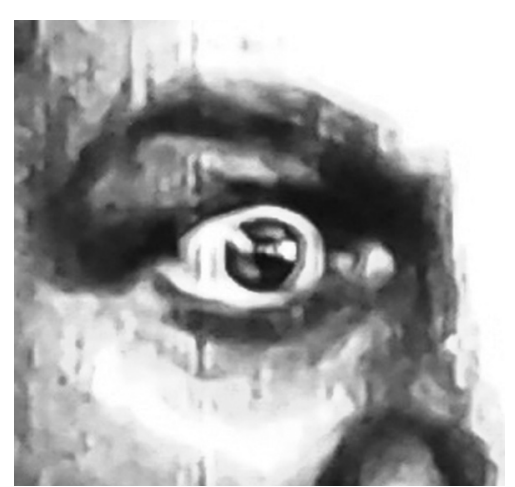

Figura 3: Detalle de la pérdida de calidad de la imagen original cinematográfica.

Es especialmente llamativo el caso de la obra Tree movie de Jackson Mac Low. La obra es de 1961 y fue concebida como un guión para realizar una película Fluxus ${ }^{51}$; de hecho, esta obra está considerada como la primera película estética. Es importante recalcar, en este caso, la condición cinematográfica de la obra, ya que en la época no existía tecnología de vídeo disponible para el uso doméstico o profesional.

De hecho, en la ficha catalográfica de la obra, disponible como texto de sala, se puede leer lo siguiente:

"La nota al pie en la partitura la convierte en un plan general: cualquier objeto puede ser el tema de la película y el elemento esencial es el emplazamiento estático de la cámara". 52

Esto pone de manifiesto que la obra fue concebida desde el primer momento como una película cinematográfica y no como una obra de vídeo. Es más, si se recurre al guión original se puede leer lo siguiente:

"Set up and focus a movie camera so that the tree* fills most of the picture. Turn on the camera and leave it on without moving it for any number of hours. If the camera is about to run out of film, substitute a camera with fresh film". ${ }^{53}$

Como se puede comprobar, el autor hace referencia, claramente, a que se trata de una filmación cinematográfica, puesto que habla tanto de la cámara cinematográfica 
como de la sustitución del soporte cinematográfico cuando este se agote. Sin embargo, la obra está catalogada como vídeo y conservada en disco duro, lo que no sería un problema si el material conservado se hubiese obtenido mediante un escaneado directo de una copia estándar de la obra original, probablemente de $16 \mathrm{~mm}$. La calidad de la proyección que se puede apreciar en la cuarta planta del MNCARS, la misma que presentaba cuando se expuso en la exposición temporal de $+/-1961$, la expansión de las artes, es de baja calidad. No es plausible que una obra concebida en 1961 mostrase esta escasa calidad de imagen y de proyección, plagada de artefactos que desfiguran la estética original de la obra, algo que debería evitarse con toda imagen cinematográfica.

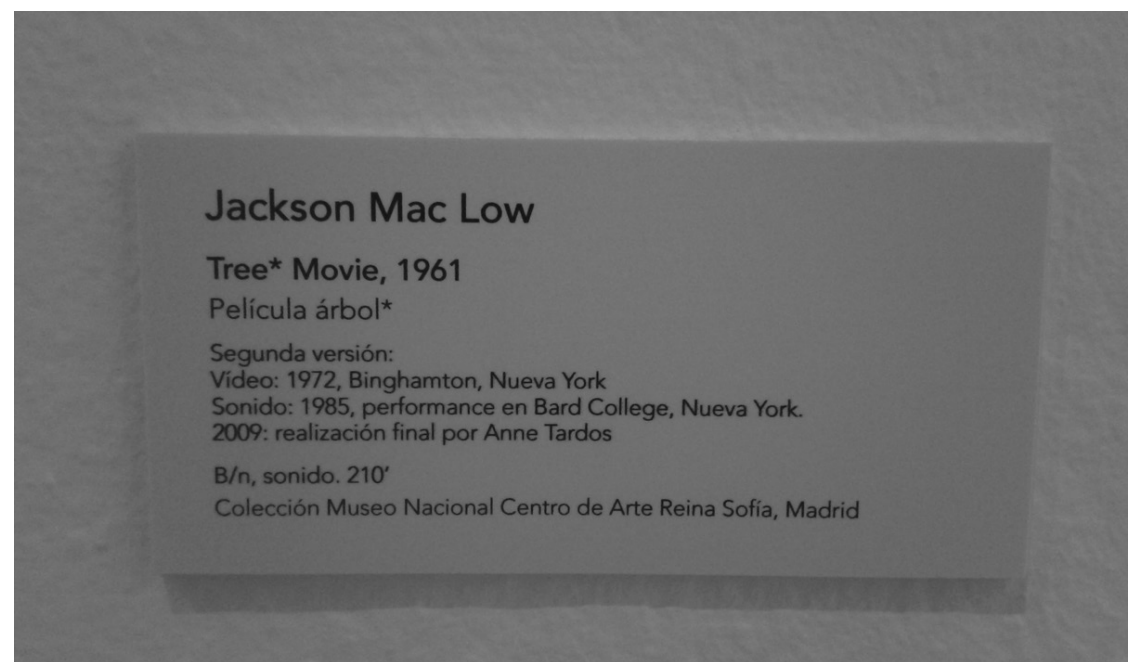

Figura 4: Detalle de la cartela de la obra Tree Movie.

Por otra parte, el sistema de proyección se basa en un reproductor de DVD y un proyector digital, lo que adultera en dos ocasiones más la obra. En primer lugar, y como ya se ha explicado, el sistema de entrelazado de la imagen de vídeo anula el sistema de sucesión de fotogramas del medio cinematográfico. Y, en segundo lugar, el sistema de proyección digital extirpa el sistema de proyección cinematográfica, basada en la transmisión de luz a través del fotograma. Por lo tanto, la obra aparece desfigurada y transformada en un material deficitario que, a pesar de ser útil desde un punto de vista documental, no tiene validez artística. En este sentido, hay que recordar que el sexto punto del informe de "Recomendaciones de uso" de la Comisión Técnica de la Federación Internacional de Archivos Fílmicos (FIAF) se 
establece que la presentación de la obra cinematográfica deberá realizarse en su formato original, cuidando todas sus características, y que, cuando esto no sea posible, deberá garantizarse, al menos, el respeto al original. ${ }^{54}$

\section{Conclusiones}

Cine y vídeo son medios distintos, con cualidades distintas y necesidades de catalogación, presentación y preservación distintas. El uso de un vocabulario difuso y erróneo es el síntoma de una incomprensión demasiado arraigada que, por desgracia, deriva en un tratamiento negligente y perjudicial de este patrimonio artístico. Ha quedado demostrado que la imagen cinematográfica se altera de forma irreversible cuando se presenta en un soporte magnético (véanse los ejemplos de las figuras 2 y 3), lo que también pone de manifiesto que la técnica de la migración de cine a vídeo como estrategia de preservación resulta inútil. Sobre todo si se tiene en cuenta que el master en Betacam digital se suele utilizar para crear una copia de exposición de la obra cinematográfica, es decir, que la imagen proyectada estará compuesta por dos mitades en lugar de mostrar al fotograma unitario original y característico.

Por otra parte, la única forma correcta de conservar un soporte artístico cinematográfico es mediante la realización de copias cinematográficas de preservación, en soporte de poliéster, o en su defecto mediante un escaneado de alta resolución que permita preservar cada fotograma de forma individual. Para ello, el master de preservación deberá ser de la misma familia que el original, es decir, respetar el formato, la anchura y sus cualidades específicas. Lo que no debe tolerarse es que un original en $35 \mathrm{~mm}$ sea preservado en soporte magnético, por mucho que este sea Betacam Digital, ya que el sistema de codificación de la información es completamente distinto y provocará la pérdida irreversible de las cualidades estéticas, características del medio original.

El uso de la pantalla y de la proyección, por otra parte, no responde a una función museológica definida, puesto que no se ajusta al medio de cada obra, y tampoco a una función museográfica, puesto que no permite al espectador extraer una información útil sobre las obras presentadas. Tampoco se usa para unificar la exposición de obras que podrían estar agrupadas bajo un mismo discurso, ya fuese

ICONO14 | Año 2014 Volumen 12 Nº 2 | ISSN: 1697-8293 | DOI: ri14.v12i2.684 
este cronológico, estilístico o temático. Sin embargo, lo que el público sí puede deducir de esta práctica tan extendida es que tanto el cine como el vídeo se pueden exponer indistintamente en pantalla y en proyección, sin que sus valores se alteren. Más aún, el público puede pensar que tanto el cine como el vídeo, al ser expuestos de forma indistinta son, en realidad, lo mismo y por eso hay ocasiones en las que el cine aparece en pantalla y otras en las que el vídeo aparece en proyección. De hecho, cuando se produzcan fallos de reproducción, como fundidos en negro, paradas abruptas o interrupciones repentinas, el espectador no podrá saber si el problema es de la técnica usada por el artista o de la tecnología utilizada para mostrar la obra. En ese sentido, Christiane Paul afirma que las instituciones deben asegurarse de que este tipo de obras se presenten de forma correcta, teniendo en cuenta la tendencia a fallar de este tipo de tecnología de reproducción, ya que es algo inevitable. ${ }^{55}$ En cualquier caso, será necesario cuantificar las probabilidades de fallo para poder decidir cómo y durante cuánto tiempo exponer una obra.

En este aspecto, los sistemas analizados no sólo no se corresponden con los originales sino que ni siquiera respetan las características originales, ya que transforman la imagen cinematográfica en imagen videográfica mediante la destrucción del fotograma unitario. El único nexo es la proyección, cuando existe, y esta ni siquiera asegura la calidad cinematográfica necesaria para emular una proyección analógica.

Todos esos errores de presentación se basan en un único punto: la incomprensión institucional del medio artístico cinematográfico y videográfico. Al no asumir las reglas de catalogación y presentación de este tipo de obras se crean aberraciones, como la presentada en la obra Tree Movie, que, a su vez, aumentan la incomprensión del público y profesionales, que sólo ven obras extrañas, incómodas o incoherentes.

\section{Notas}

[1] Con obras como Ritmo 21, de 1921, Ballet mecánico, de 1924, y Sinfonía diagonal, de 1925.

[2] Al que se considera el padre intelectual del videoarte con la grabación en vídeo de la visita del Papa Pablo VI a Nueva York, en 1965. Fue el primer artista en usar el modelo de cámara doméstica "Portapack" de Sony.

DOI: ri14.v12i2.684 | ISSN: 1697-8293 | Año 2014 Volumen 12 №2 | ICONO14 
[3] El Museo de Arte Moderno de Nueva York fue el primero en crear, en la década de los años treinta del siglo XX, un departamento de "Film". Sin embargo, su función no era el estudio de la obra de arte cinematográfica, como deseaba su director, A. H. Barr, sino mostrar al público general documentales especializados y películas comerciales. Tal era su orientación que se contrató a la eminente crítica cinematográfica Iris Barry para dirigirlo, con gran éxito de público. Merece también la pena destacar que el Museo Whitney, vecino del anterior, fue fundado sobre las bases del "Whitney Cine Club", fundado a su vez por Cornelius Vanderbilt.

[4] En este caso no hay que olvidar que se está hablando de instituciones de arte contemporáneo, en la que la presencia del vídeo y del cine es exigida como rasgo de modernidad. Se podría decir que no hay exposición contemporánea que no muestre, en algún momento, una obra de estas características.

[5] El significado de este término, según el diccionario de la Real Academia Española, en su única acepción reconocida, es "que se refiere conjuntamente al oído y a la vista, o los emplea a la vez. Se dice especialmente de métodos didácticos que se valen de grabaciones acústicas acompañadas de imágenes ópticas". Por lo tanto, su uso no es pertinente al hacer referencia a un número diverso de actividades de diferente naturaleza, no sólo artísticas.

[6] Lafuente, I.T., (2013) Tesauro y Diccionario de objetos asociados a la expresión artística. Tesauro y Diccionario para la descripción y catalogación de bienes culturales. Madrid: Ministerio de Educación Cultura y Deporte.

[7] Para cuantificar las obras que cada colección posee se ha tomado como referencia los catálogos publicados y los disponibles en las respectivas páginas electrónicas, permitiendo, de este modo, trazar un mapa bastante aproximado de las principales colecciones de arte contemporáneo de España.

[8] Lafuente, I.T., (2013) Tesauro y Diccionario de objetos asociados a la expresión artística. Tesauro y Diccionario para la descripción y catalogación de bienes culturales. Madrid: Ministerio de Educación Cultura y Deporte.

[9] Los tesauros publicados por el Ministerio de Cultura para unificar el proceso de catalogación, directamente relacionado con la base de datos DOMUS, corresponden a materiales cerámicos (2002), mobiliario (2005), materiales y técnicas (2008), numismática (2009), objetos relacionados con cultos y religiones (2011) y, por último, objetos asociados a la expresión artística (2013); este último es el que precisamente recoge los términos necesarios expuestos previamente.

[10] Lafuente, Ibidem, pp. 109 - 337.

[11] Diccionario de la Real Academia Española, versión para Internet, enlace consultado el 30 de diciembre de 2012, y disponible en http://lema.rae.es/drae/?val=fotograma.

[12] Véase "filmina", en este mismo apartado.

[13] Diccionario de la Real Academia Española, versión para Internet consultada el 30 de diciembre de 2012. Enlace disponible en: http://lema.rae.es/drae/?val=grabar

[14] Lafuente, 0p. Cit., p. 210.

[15] Ibidem, p. 255.

ICONO14 | Año 2014 Volumen 12 Nº 2 | ISSN: 1697-8293 | DOI: ri14.v12i2.684 
[16] Ibidem, p. 195.

[17] Las dos acepciones de "filmina" son: 1) Cada una de las diapositivas de una serie organizada con propósitos pedagógicos; 2) Diapositiva.

[18] Lafuente, 0p. Cit. p. 298.

[19] http://lema.rae.es/drae/?val=VIDE0GRABACI\%C3\%93N

[20] Ayuntamiento de Vitoria, Diputación Foral de Álava, Gobierno Vasco y Ministerio de Cultura.

[21] Diario El Correo, Euskaltel y Naturgas Energía.

[22] "Sobre la colección", página electrónica de Artium, consultado el tres de diciembre de 2012. Recurso disponible en: http://www.artium.org/Castellano/Colecci\%C3\%B3n/ SobreLaColecci\%C3\%B3n/tabid/103/language/es-ES/Default.aspx

[23] Rossell, Benet - Valors esperats: $2+1=<\mathrm{f}(\mathrm{x})>=$ ? $\mathrm{f}(\mathrm{x})$ ?² $\left.^{2} \mathrm{x}\right) \mathrm{dx} \sim 2+2,1978$.

[24] Artium Centro Museo Vasco de Arte Contemporáneo; La colección, Diputación Foral de Álava y Artium, Vitoria, 2004, p. 58.

[25] Decreto 195/1997, de 29 de julio, por el que se aprueban los Estatutos del Centro Andaluz de Arte Contemporáneo. B0JA n 107, de 13 de septiembre de 1997.

[26] Memoria anual de actividades del año 2011, Museo Guggenheim Bilbao, Bilbao, 2011, p. 6.

[27] Colección del Museo Guggenheim Bilbao, TF y Museo Guggenheim Bilbao, Bilbao, 2009, p. 256.

[28] Ibidem, pp. 486 y 487.

[29] Ibidem, pp. 462 y 463.

[30] En sus artículos 14 a 26 se regula su régimen jurídico básico.

[31] Entidad de derecho público de las previstas en el párrafo segundo del artículo 5.2 del Decreto Legislativo de 26 de junio de 1991, por el que se aprobó el texto refundido de la Ley de Hacienda Pública de la Generalitat Valenciana.

[32] Instalaciones y Nuevos Medios en la colección del IVAM. Espacio, tiempo, espectador, Instituto Valenciano de Arte Moderno, Valencia, 2006, pp. 231 - 234.

[33] Información extraída de la página electrónica oficial del IVAM, disponible en el enlace: http:// www.ivam.es/collections/1-ejes-de-la-coleccin

[34] La colección del IVAM, Madrid: Instituto Valenciano de Arte Moderno y Aldeasa, 2001.

[35] "El Macba cuenta con 4.674 obras, la mayoría de los años sesenta y setenta", diario El País, edición Cataluña, 24 de noviembre de 2012.

[36] Resultados de la búsqueda obtenidos del catálogo de Internet de la institución. Recurso disponible en el siguiente enlace: www.macba.cat/es/search_collection?flag=5\&query=\&artist= \&title=\&y=\&type\%5B\%5D=180\#form_adv_search.

[37] Colección MACBA, Barcelona: Museu d'Art Contemporani de Barcelona, 2003; pp. 197 - 207.

[38] Año en el que se derriba el Muro de Berlín y se reunifica Alemania. Esta fecha, además

DOI: ri14.v12i2.684 | ISSN: 1697-8293 | Año 2014 Volumen 12 №2 | ICONO14 
de la reunificación alemana, representa la apertura de la escena artística europea y la incorporación de artistas que antes se encontraban aislados en la parte comunista del mencionado país. Esto supone una transformación radical del panorama artístico internacional.

[39] Sin acento en la " $\mathrm{i}$ ", la errata merece la atención de la investigación ya que denota un error de catalogación importante.

[40] Resultados obtenidos al realizar la búsqueda en el catálogo de la colección disponible en la página electrónica. Recurso disponible en el siguiente enlace: http://www.musac.es/\#coleccion/ artistas/

[41] Accenture, S.L.; ACS, Actividades de Construcción y Servicios, S.A.; Aon Gil y Carvajal, S.A.; Banco Bilbao Vizcaya Argentaria, S.A.; Banco Pastor, S.A.; Bodegas Vega Sicilia, S.A.; Fernando de la Cámara García; Cartera Industrial Rea, S.A.; Colecciones de Arte, S.A.; Ebro Puleva, S.A.; Electra del Jallas, S.A.-Grupo Gas Natural; Carlos Entrena Palomero; Finisterre, S.A.; Gas Natural-Unión Fenosa; Hullas del Coto Cortés, S.A.; Hullera Vasco Leonesa, S.A.; Lignitos de Meirama, S.A.-Grupo Gas Natural; Navarro Generación, S.A.; Pedro Navarro Martínez; S.G.L. Carbón, S.A.; Técnicas Reunidas S.A.; Tilifor, S.L.; Zara España, S.A.

[42] Museo Patio Herreriano, Arte contemporáneo español. Valladolid: Museo Patio Herreriano, 2002; p. 28.

[43] Catálogo disponible en el enlace: http://www.museoreinasofia.es/coleccion y consultado el 30 de diciembre de 2012 para la presente investigación.

[44] Por elemento tecnológico audiovisual se hace referencia a monitores, pantallas planas y proyecciones sobre pared, que van unidos, todos ellos, a reproductores de DVD, altavoces o auriculares y proyectores digitales, en función de la modalidad de exposición usada. La unidad básica, por tanto, es un reproductor de DVD, con un soporte de DVD en su interior, que es reproducido, con sonido o sin él, en un monitor, una pantalla o una proyección.

[45] Por pieza audiovisual se hace referencia al contenido de imágenes y sonido reproducido en el dispositivo tecnológico y que no se corresponde en todas las ocasiones con obra de arte, como se va ha describir a continuación.

[46] El público no es capaz de comprender el uso que se hace de la proyección o de la televisión, ni su pertinencia, porque su uso es indiscriminado, como se va a analizar a continuación, y no establece ninguna diferencia en su aplicación.

[47] Como por ejemplo: Eduardo Arroyo, exposición individual, Festivales de España $n^{\circ} 1$, Nuevos realismos, estrategias del objeto o Arte en un mundo dividido, todos ellos en el área de consulta de la cuarta planta del edificio de Sabatini. Hay que recordar que algunos de ellos comparten el mismo televisor, por lo que el número de elementos audiovisuales, televisores y pantallas (61), no coincide con el número de piezas, que son cinco más (65).

[48] Bienvenido Mr Marshall, de Berlanga, La ventana Indiscreta, de Hitchcock, Rebelde sin causa, de Ray, La guerra a terminado, de Resnais, Los olvidados, de Buñuel o Una semana, de Buster Keaton, entre otras.

[49] Visita a Oscar Domínguez de Alain Resnais, en la segunda planta del edifício de Sabatini.

ICONO14 | Año 2014 Volumen 12 Nº 2 | ISSN: 1697-8293 | DOI: ri14.v12i2.684 
[50] El 27,6\% de las piezas audiovisuales expuestas son, por tanto, obras cedidas. Cuatro de ellas comparten la misma proyección sobre fondo negro.

[51] Fluxfilm, en inglés.

[52] Ficha catalográfica de la obra impresa disponible en la sala 423 del edificio Sabatini.

[53] Expuesto junto a la proyección, en la sala 423 de la cuarta planta del edificio de Sabatini.

[54] “Con el fin de asegurar la presentación de una imagen auténtica, la proyección o el sistema de difusión deberán ser capaces de tratar correctamente el elemento fílmico. La exhibición deberá seguir los mismos criterios de autenticidad que rigen las demás etapas de la preservación de las obras cinematográficas. Las películas deberán ser exhibidas en su formato y cuidando todas las características de esa experiencia fílmica concreta; no obstante, atendiendo a que los cambios tecnológicos no siempre permiten la reproducción exacta de los sistemas de exhibición originales, debe considerarse la tolerancia de un cierto grado de "transformación" en las presentaciones a través de las plataformas de difusión actuales. Estas versiones "modernas" siempre deben aspirar a mantener el principio de autenticidad." Recomendaciones de uso de la Comisión Técnica de la FIAF, Comisión Técnica de la FIAF, Federación Internacional de Archivos Fílmicos, 2009, sexto punto, p. 6.

[55] Paul, C., (2008) "Challenges for a Ubiquitous Museum", New Media in the White Cube and Beyond. Curatorial Models for Digital Art. Berkeley: Universidad de California y California Press; p. 68.

\section{Referencias}

Artium Centro Museo Vasco de Arte Contemporáneo. (2004). La colección. Vitoria: Diputación Foral de Álava y Artium.

Bradley, K. (2006). Risks associated with the use of recordable CDs and DVDs as reliable storage media in archival collections - Strategies and alternatives. París: UNESCO.

Besser, H. (1987). Digital Images for Museums, Museum Studies Journal, 3, otoñoinvierno; pp. 74-81.

Besser, H. (2001). Digital Preservation of Moving Image Material, The Moving Image: The Journal of the Association of Moving Image Archivists. 1, p. 2. Bosco, R. (2012). El Macba cuenta con 4.674 obras, la mayoría de los años sesenta y setenta. Barcelona, El País, edición impresa de Cataluña, 24 de noviembre de 2012, p. 7.

Comisión Técnica de la Federación Internacional de Archivos Fílmicos. (2009). Recomendaciones de uso de la Comisión Técnica de la FIAF. Bruselas:

Federación Internacional de Archivos Fílmicos.

Hanhardt, J. G. (2001). Preserving the Inmaterial. Nueva York: Solomon R. Guggenheim Museum.

DOI: ri14.v12i2.684| ISSN: 1697-8293 | Año 2014 Volumen 12 № 2 | ICONO14 
Ippolito, J. (1998). The Museum of the Future: A Contradiction in Terms?, Artbyte (1), 2 (junio-julio), pp. 18-19.

Instituto Valenciano de Arte Moderno. (2006). Instalaciones y Nuevos Medios en la colección del IVAM. Espacio, tiempo, espectador. Valencia: Instituto Valenciano de Arte Moderno.

Instituto Valenciano de Arte Moderno. (2001). La colección del IVAM. Madrid: Instituto Valenciano de Arte Moderno y Aldeasa.

Lafuente, I. T. (2013). Tesauro y Diccionario de objetos asociados a la expresión artística. Tesauro y Diccionario para la descripción y catalogación de bienes culturales. Madrid: Ministerio de Educación Cultura y Deporte.

Martin, A. L. (Ed.). (2001). AMIA compendium of moving image cataloguing practice. Chicago: Association of Moving Image Archivists and Society of American Archivists.

Mattock, L. K. (2010). From film restoration to digital emulation, The archival code of ethics in the age of digital reproduction. Journal of Information Ethics, 19 (1), pp. 74-85. DOI: 10.1.743172/JIE.19.1.74.

Museu d'Art Contemporani de Barcelona. (2003). Colección MACBA. Barcelona:

Museu d'Art Contemporani de Barcelona.

Museo Guggenheim Bilbao. (2009). Colección del Museo Guggenheim Bilbao, Bilbao: TF y Museo Guggenheim Bilbao.

Museo Guggenheim Bilbao. (2011). Memoria anual de actividades del año 2011. Bilbao: Museo Guggenheim Bilbao.

Museo Patio Herreriano. (2002). Museo Patio Herreriano, Arte contemporáneo español. Valladolid: Museo Patio Herreriano.

Paul, C. (2008). Challenges for a Ubiquitous Museum, New Media in the White Cube and Beyond. Curatorial Models for Digital Art. Berkeley: Universidad de California y California Press.

Rotaeche, M. (2011). Conservación y restauración de materiales contemporáneos y nuevas tecnologías. Madrid: Editorial Síntesis.

Wasson, H. (2005) Museum Movies. The Museum of Modern Art and the Birth of the Art Cinema. Los Ángeles, Berkley y Londres: University of California Press.

Yee, M. (2007). Moving image cataloguing: How to create and how to use a moving image catalog. Westport: Libraries Unlimited. 